\title{
DETERMINANTS OF CORPORATE SOCIAL RESPONSIBILITY DISCLOSURE IN INDONESIA
}

\author{
BELA SULISTYAGUNA*, YULI CHOMSATU SAMROTUN, ENDANG \\ MASITOH WAHYUNINGSIH
}

Accounting Department, Faculty of Economics, Batik Islamic University of Surakarta

*Email: belasulistyaguna@icloud.com

\begin{abstract}
Corporate social responsibility is the company's obligation to the stakeholders to be seen as a responsible business entity. The purpose of this research was to analyze the influence of company size, company age, industry type, liquidity, profitability, leverage, board of directors, board of commissioners, audit committee, and public ownership on the corporate social responsibility disclosure. Analysis of data using multiple linear regression method with SPSS 22.0 for mac. The sample consists of companies listed on the Indonesia Stock Exchange (IDX) and disclosed the Global Reporting Initiative (GRI) sustainability reports from 2013 to 2018. The final sample of this research was 18 companies that obtained by purposive sampling. The results of the research showed that, simultaneously, company size, company age, industry type, liquidity, profitability, leverage, board of directors, board of commissioners, audit committee, and public ownership have an influence on the corporate social responsibility disclosure. Partially, the results showed that liquidity and leverage have an influence on corporate social responsibility disclosure. Meanwhile, company size, company age, industry type, profitability, board of director, board of commissioner, audit committee, and public ownership has no influence on corporate social responsibility disclosure.
\end{abstract}

Keywords: Corporate Social Responsibility; CSR Disclosure; Indonesian Listed Companies

\section{INTRODUCTION}

In addition to the company's financial disclosures, there are other disclosures that stakeholders would expect, which is corporate social responsibility disclosure. Corporate social responsibility should be based on the triple bottom lines: social, environmental and financial. The existence of a framework of social responsibility reporting concepts that can be used is the Global Reporting Initiative in the form of sustainability reports. However, not a few companies have not disclosed social responsibility activities in a company sustainability report.

The information required to process short-term and long-term decision making. The more company gives a contribution to the environment, the better the

* Corresponding author's e-mail: belasulistyaguna@icloud.com

http://openjournal.unpam.ac.id/index.php/JIA 
Jurnal Ilmiah Akuntansi Universitas Pamulang - Vol. 9, No. 1, Januari 2021 -

Sulistyaguna et al

company image in the public's view. Corporate social responsibility activities are considered as voluntary efforts undertaken by companies, they want to satisfy their customers and other stakeholders socially and increase the value of their company in relation to their community and the overall social environment. A company's awareness of its importance the corporate social responsibility disclosure is based on the idea that companies do not only have economic and legal obligations to shareholders but also obligations to other interested parties.

Research gap which becomes a reference in this research conducted by Zaid $\&$ Nasiri (2018) found that company size has a relationship with the CSR disclosure. The opposite result was found by Mukhtaruddin et al (2018). Salehi et al (2019) found that company age and industry type has a relationship with the CSR disclosure. The opposite result was found by Issa (2017). Nasution et al (2018) found that profitability, leverage and liquidity has a relationship with the CSR disclosure. The opposite result was found by Santika et al (2019). Anatami et al (2019) found that board of directors and audit committee has a relationship with the CSR disclosure. The opposite result was found by Osei et al (2017). Handayati \& Rochayatun (2015) found that board of commissioners and public ownership has a relationship with the CSR disclosure. The opposite result was found by Ramadhani \& Agustina (2019).

\section{LITERATURE REVIEW}

\section{Agency Theory}

Agency theory explains the relationship between the principal (owner of the company) and the agent (manager). A bigger company, the bigger cost of the agency. Large companies have many areas of business and tend to disclose social information more broadly.

\section{Stakeholders Theory}

In stakeholder theory, companies will maximize their business so that they can get full support from stakeholders. Stakeholders are all parties, internal and external, that can influence or be influenced by the company either directly or indirectly. One way to get support, especially from outside parties, is to express corporate social responsibility.

\section{Legitimacy Theory}

Legitimacy is a system of corporate management oriented to alignments with society, government, and individuals. For this reason, as a system that prioritizes alignments with society, the company's operations must be congruent with the expectations of society.

\section{Corporate Social Responsibili-ty (CSR) Disclosure}

CSR is a continuing commitment from companies that conduct ethically and contribute to development to improve the quality of life of workers and their families, as well as local communities and the wider community. Disclosure of social responsibility is the process of communicating the social impact of the

* Corresponding author's e-mail: belasulistyaguna@icloud.com

http://openjournal.unpam.ac.id/index.php/JIA 
Jurnal Ilmiah Akuntansi Universitas Pamulang - Vol. 9, No. 1, Januari 2021 -

Sulistyaguna et al

organization's economic activities towards special interest groups and the community as a whole.

\section{Company Size}

Large companies will reveal more social information to legitimize the impacts caused by company activities and to fulfill the desires of stakeholders with an interest in corporate social responsibility. Joshi \& Hyderabad (2019) found that company size influences on CSR disclosure.

H1: Company size influences on CSR disclosure.

\section{Company Age}

The longer of company survives, the company will be increasingly recognized existence and excellence in the public views. It is expected that the company will be more extensive in carrying out CSR disclosures. Coluccia et al (2018) found that company age influences on CSR disclosure.

$\mathrm{H} 2$ : Company age influences on CSR disclosure.

\section{Industry Type}

Companies tend to disclose more CSR information to demonstrate their social responsibility to their community, to enhance their image and increase profits. For example, the manufacturing sector discloses more about community, safety and health related to CSR categories, while in the oil sector higher disclosure in environmental categories occurs. In this research, the classification of industrial type refers to Hackston \& Milne (1996)'s research, which includes "the agriculture, forestry, fishing, mining and mining service, construction, etc" as high profile, while "animal feed and husbandry, textile mill products, apparel and other textile products, lumber and wood products, etc" as low profile. Salehi et al (2019) found that industry type influences on CSR disclosure.

H3: Industry type influences on CSR disclosure.

\section{Liquidity}

The lower the level of company liquidity, the higher the disclosure of social responsibility. Liquidity is one performance that is often used as a benchmark for investors in valuing companies. Therefore, when the liquidity produced is low, companies will tend to make more CSR disclosures. Gantyowati \& Agustine (2017) found that liquidity effects on CSR disclosure in Indonesia.

H4: Liquidity influences on CSR disclosure.

\section{Profitability}

Profitability is the company's ability to generate profits which is a net result of management policies. The higher of profitability, the higher CSRD will be done by the company. Zaid \& Nasiri (2018) found that profitability effects on CSR disclosure.

H5: Profitability influences on CSR disclosure.

* Corresponding author's e-mail: belasulistyaguna@icloud.com

http://openjournal.unpam.ac.id/index.php/JIA 
Jurnal Ilmiah Akuntansi Universitas Pamulang - Vol. 9, No. 1, Januari 2021 -

Sulistyaguna et al

\section{Leverage}

Company that owns high level of leverage, assuming it is necessary to report social responsibility disclosures, so there is "good news" about company performance. Ariyani \& Hartomo (2018) found that leverage influences on CSR disclosure.

H6: Leverage influences on CSR disclosure.

\section{Board of Directors}

Board of directors are one of the most important elements of corporate governance. The more directors, the collective experience and expertise of the board increased, and therefore, the need for CSR disclosure will be higher. Naseem et al (2017) found that board of directors effects on CSR disclosure.

H7: Board of directors influences on CSR disclosure.

\section{Board of Commissioners}

The board of commissioners can provide a strong enough influence to pressure management to disclose more CSR information, so it can be explained that if companies have a larger size of the board of commissioners will disclose CSR more. Hermawan \& Gunardi (2019) found that board of commissioners effects on CSR disclosure.

H8: Board of commissioners influences on CSR disclosure.

\section{Audit Committee}

The size of the audit committee in the company as one mechanism in GCG is expected to be able supervise management, responsibility towards the community and environment around the company, so the desire of stakeholders to implement CSR and disclose it to public audiences can be guaranteed. Anatami et al (2019) found that audit committee effects on CSR disclosure.

H9: Audit committee influences on CSR disclosure.

\section{Public Ownership}

The greater shares owned by the public, company will be more extensive in expressing social responsibility and endeavor as well as possible to get support from public. Suhartono et al (2018) found that public ownership effects on CSR disclosure.

H10: Public ownership influences on CSR disclosure.

\section{RESEARCH METHOD}

This research is quantitative research with the type of data used is secondary data. The technique of data collection was done by documentation technique on annual reports and sustainability reports that have been officially published on the website of www.idx.co.id and company's website.

The sampling technique used was purposive sampling which can be seen in Table 1. In Issa (2017), "financial institutions such as banking and insurance sectors

* Corresponding author's e-mail: belasulistyaguna@icloud.com

http://openjournal.unpam.ac.id/index.php/JIA 
Jurnal Ilmiah Akuntansi Universitas Pamulang - Vol. 9, No. 1, Januari 2021 -

Sulistyaguna et al

are excluded because of their distinctive features and the different requirements of disclosure". The measurement of each variable will be explained in table 2 .

Table 1

The Process of Selecting Research Samples

\begin{tabular}{cc}
\hline \multicolumn{1}{c}{ Criteria } & Total \\
\hline No & $\begin{array}{l}\text { Companies that listed on the Indonesia Stock Exchange } \\
\text { from 2013-2018 }\end{array}$ \\
$\begin{array}{l}\text { Companies that are not issued and publish annual reports } \\
\text { \& sustainability reports consistently and companies that }\end{array}$ & 388 \\
2. have not complete data in accordance with the research & $(362)$ \\
variables & \\
3. Banking and insurance companies & $(8)$ \\
Total of companies sampled & 18 \\
Total years of research & 6 \\
Total units of analysis & 108 \\
Outliers & $(29)$ \\
Amount of data & 79 \\
Source: Secondary Data Processed &
\end{tabular}

Table 2: Measurement of Research Variables

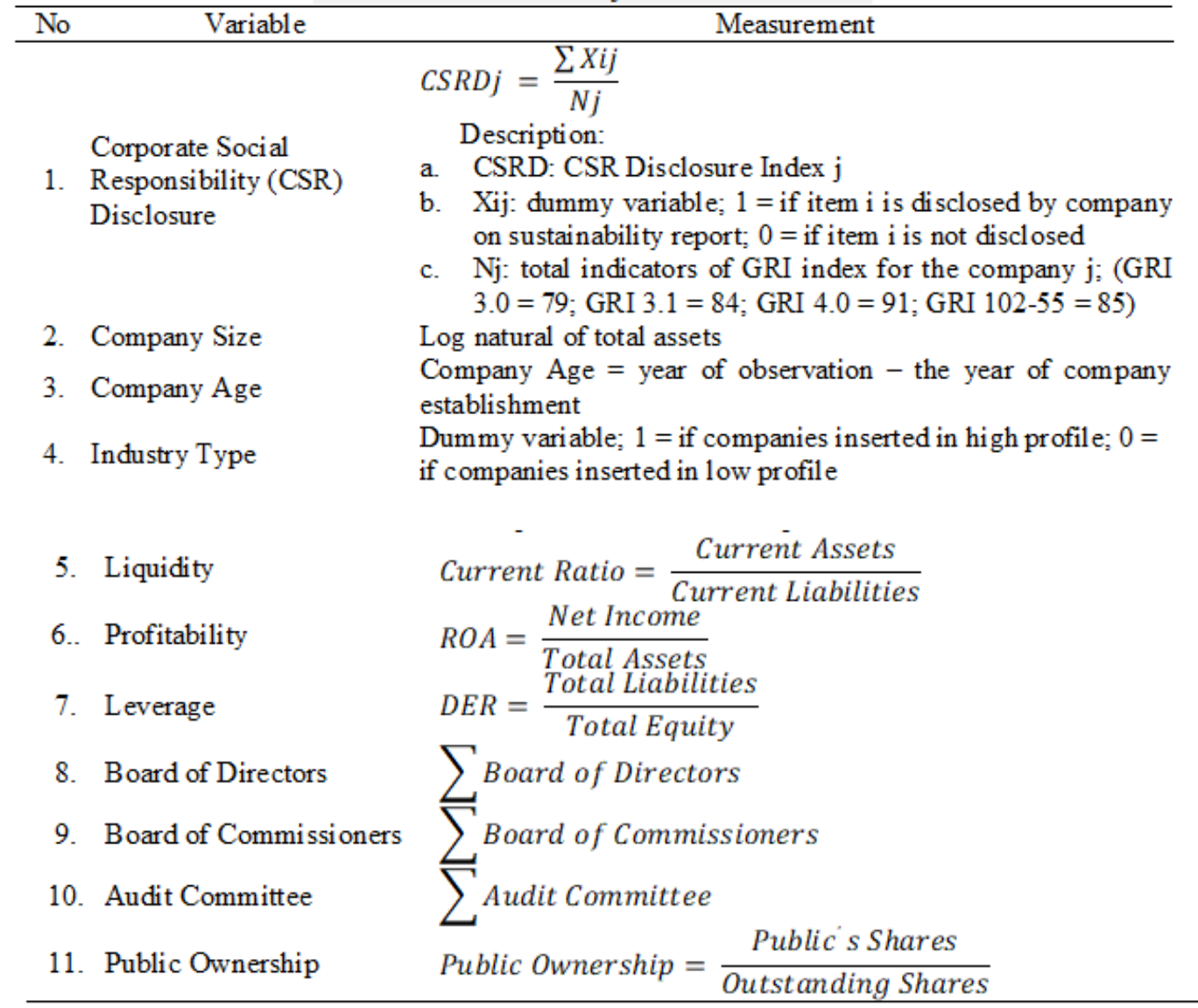

Source: Secondary Data Processed

Data analysis used a multiple linear regression method with SPSS 22.0 for mac. Data analysis technique used were descriptive statistics analysis, the classical assumption test, and multiple linear regression. The regression models used in this study are as follows:

* Corresponding author's e-mail: belasulistyaguna@icloud.com

http://openjournal.unpam.ac.id/index.php/JIA 
Jurnal Ilmiah Akuntansi Universitas Pamulang - Vol. 9, No. 1, Januari 2021 -

Sulistyaguna et al

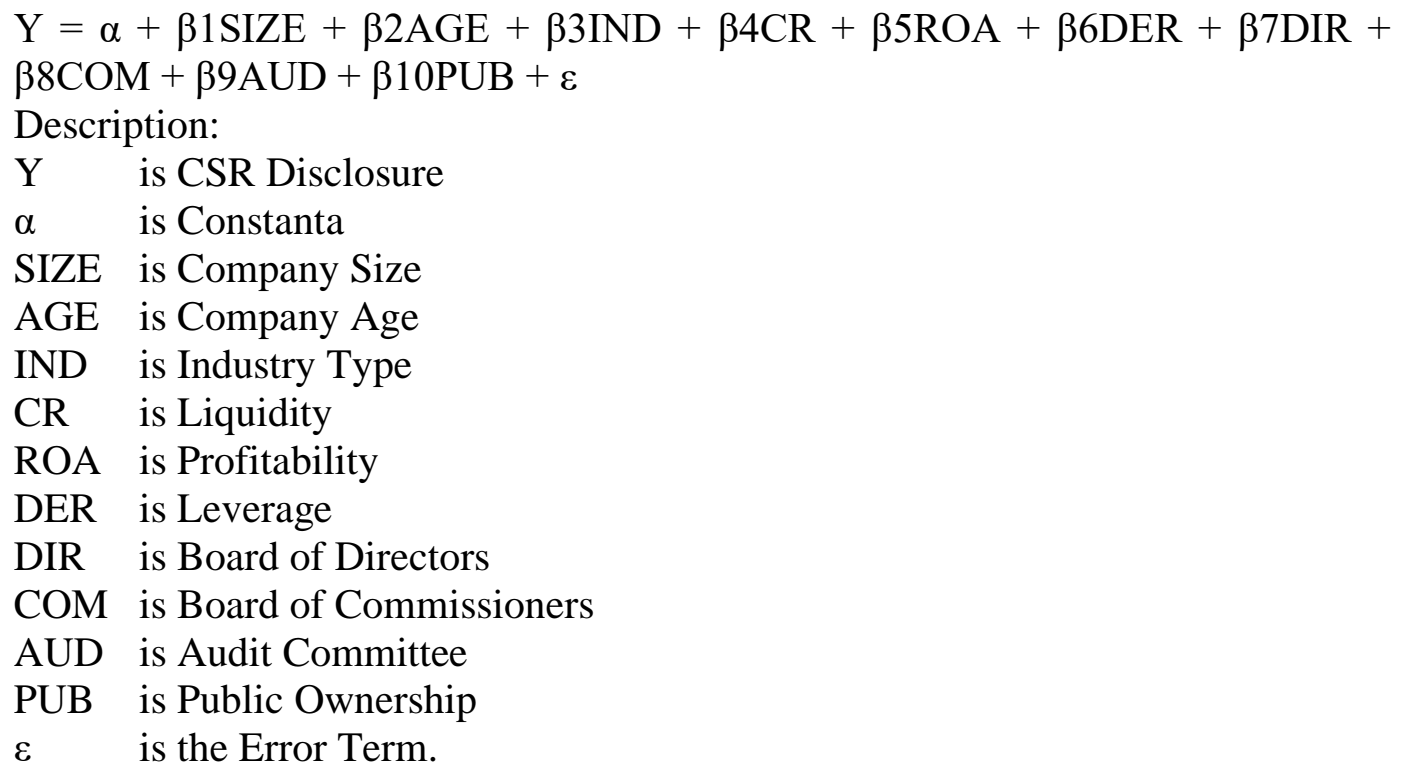

\section{RESULTS AND DISCUSSION}

The results of the descriptive statistics analysis, serving in the table below:

Table 3 : Descriptive Statistics Analysis

\begin{tabular}{cccccc}
\hline & N & Minimum & Maximum & Mean & $\begin{array}{c}\text { Std. } \\
\text { Deviation }\end{array}$ \\
\hline X1_SIZE & 79 & 28,43 & 32,39 & 30,7793 & 0,93020 \\
X2_AGE & 79 & 13,00 & 68,00 & 41,8354 & 13,87899 \\
X3_IND & 79 & 0,00 & 1,00 & 0,7722 & 0,42212 \\
X4_CR & 79 & 0,38 & 3,19 & 1,6121 & 0,62991 \\
X5_ROA & 79 & $-0,06$ & 0,21 & 0,0653 & 0,06049 \\
X6_DER & 79 & 0,20 & 3,18 & 1,2282 & 0,75909 \\
X7_DIR & 79 & 3,00 & 9,00 & 6,1899 & 1,31145 \\
X8_COM & 79 & 3,00 & 9,00 & 5,9114 & 1,31256 \\
X9_AUD & 79 & 3,00 & 7,00 & 3,6582 & 0,88992 \\
X10_PUB & 79 & 16,76 & 49,00 & 33,5960 & 8,36386 \\
Y_CSRD & 79 & 0,09 & 0,73 & 0,3299 & 0,16732 \\
ValidN(listwise) & 79 & & & & \\
\hline
\end{tabular}

Source : Data Analysis Result (SPSS)

\section{Normality Test}

The normality test of this research using the Kolmogorov-Smirnov test. This test aims to check whether the data is normally distributed. Based on the result of the table below, the value of Asymp. Sig. 2-tailed is 0,2 which is higher than 0,05. Therefore, the data is normal. 
Jurnal Ilmiah Akuntansi Universitas Pamulang - Vol. 9, No. 1, Januari 2021 -

Sulistyaguna et al

Table 4: Normality Test (Kolmogorov-Smirnov)

\begin{tabular}{ccccc}
\hline Variable & $\mathrm{N}$ & $\begin{array}{c}\text { Asymp. Sig 2- } \\
\text { tailed }\end{array}$ & $\begin{array}{c}\text { Significance } \\
\text { Level }\end{array}$ & Description \\
\hline Unstandardized Residual & 79 & 0,2 & $>0,05$ & Normal \\
\hline
\end{tabular}

Source : Data Analysis Result (SPSS)

\section{Multicollinearity Test}

The Multicollinearity test aims to find out there or whether the same relationship between the independent variables used. Based on the results of the table below, the tolerance value of variables are more than 0,1 and VIF value of variables is less than 10 , so there is no multicollinearity, between the variables.

Table 5 : MulticollinearityTest (Variance Inflation Factor)

\begin{tabular}{cccccl}
\hline \multirow{2}{*}{ Variable } & \multicolumn{2}{c}{ Tolerance } & \multicolumn{2}{c}{ VIF } & Description \\
\hline X1_SIZE & 0,481 & $>0,1$ & 2,080 & $<10$ & No Multicollinearity \\
X2_AGE & 0,603 & $>0,1$ & 1,659 & $<10$ & No Multicollinearity \\
X3_IND & 0,513 & $>0,1$ & 1,950 & $<10$ & No Multicollinearity \\
X4_CR & 0,703 & $>0,1$ & 1,423 & $<10$ & No Multicollinearity \\
X5_ROA & 0,653 & $>0,1$ & 1,531 & $<10$ & No Multicollinearity \\
X6_DER & 0,556 & $>0,1$ & 1,799 & $<10$ & No Multicollinearity \\
X7_DIR & 0,681 & $>0,1$ & 1,469 & $<10$ & No Multicollinearity \\
X8_COM & 0,860 & $>0,1$ & 1,163 & $<10$ & No Multicollinearity \\
X9_AUD & 0,544 & $>0,1$ & 1,839 & $<10$ & No Multicollinearity \\
X10_PUB & 0,467 & $>0,1$ & 2,143 & $<10$ & No Multicollinearity \\
\hline
\end{tabular}

Source : Data Analysis Result (SPSS)

\section{Autocorrelation Test}

The autocorrelation test was conducted to find out the level of relations between variables in a single observation. Based on the table below, the result shows that Asymp. Sig. (2-tailed) $>0,05$, so there is no autocorrelation.

\begin{tabular}{cccc}
\multicolumn{4}{c}{ Table 6: Autocorrelation Test (Run Test) } \\
\hline Variable & Asymp. Sig 2-tailed & Standard & Description \\
\hline $\begin{array}{c}\text { Unstandardized } \\
\text { Residual }\end{array}$ & 0,054 & $>0,05$ & No Autocorrel ation \\
\hline
\end{tabular}

Source : Data Analysis Result (SPSS)

\section{Heteroscedasticity Test}

Heteroscedasticity test aims to analyze, the occurrence of inequalities between the residual. Based on the table below, the result shows that the correlation between independent variables and unstandardized residual value (Sig. 2 tailed) are more than 0,05 , so there is no heteroscedasticity.

* Corresponding author's e-mail: belasulistyaguna@icloud.com

http://openjournal.unpam.ac.id/index.php/JIA 
Jurnal Ilmiah Akuntansi Universitas Pamulang - Vol. 9, No. 1, Januari 2021 -

Sulistyaguna et al

Table 7: Heteroscedasticity Test (Spearman's Rho)

\begin{tabular}{cccl}
\hline Variable & Sig. 2 tailed & Standard & Description \\
\hline X1_SIZE & 0,998 & $>0,05$ & No Heteroscedasticity \\
X2_AGE & 0,732 & $>0,05$ & No Heteroscedasticity \\
X3_IND & 0,963 & $>0,05$ & No Heteroscedasticity \\
X4_CR & 0,859 & $>0,05$ & No Heteroscedasticity \\
X5_ROA & 0,669 & $>0,05$ & No Heteroscedasticity \\
X6_DER & 0,891 & $>0,05$ & No Heteroscedasticity \\
X7_DIR & 0,936 & $>0,05$ & No Heteroscedasticity \\
X8_COM & 0,831 & $>0,05$ & No Heteroscedasticity \\
X9_AUD & 0,660 & $>0,05$ & No Heteroscedasticity \\
X10_PUB & 0,722 & $>0,05$ & No Heteroscedasticity \\
\hline
\end{tabular}

Source : Data Analysis Result (SPSS)

\section{The Regression Model}

Based on the result of regression analysis, the regression model in this study: $\mathrm{Y}=0,315+0,006 \mathrm{SIZE}+0,001 \mathrm{AGE}+0,104 \mathrm{IND}-0,110 \mathrm{CR}+0,266 \mathrm{ROA}-$ $0,112 \mathrm{DER}+0,008 \mathrm{DIR}+0,002 \mathrm{COM}+0,013 \mathrm{AUD}-0,003 \mathrm{PUB}$

\section{The Simultaneous Test (F Test)}

The simultaneous test of this research using the $\mathrm{F}$ test. F statistic test shows the effect of all independent variables that are meant in the model simultaneously to the dependent variable. Based on the table below, the results obtained that $F$ count $>\mathrm{F}$ table value and Sig. value $<0,05$. It means that independent variables simultaneously influence on the dependent variable.

\begin{tabular}{ccccc} 
& \multicolumn{2}{c}{ Table 8 : Simultaneous Test } & (F Test) & \\
F Count & F Table & Sig. & Standard & Description \\
\hline 3,170 & $>1,97$ & 0,002 & $<0,05$ & Proper \\
\hline Source : Data Analysis Result (SPSS) & & &
\end{tabular}

\section{The Hypothesis Test (t-Test)}

The hypothesis test of this research using t-test. Based on the table below, if $\mathrm{t}$ count value $>\mathrm{t}$ table and Sig. $<0,05$ it means that independent variables partially influence the dependent variable.

Table 9: Hypothesis Test (t Test)

\begin{tabular}{cccccc}
\hline Hypothesis & t Count & t Table & Sig. & Standard & Description \\
\hline X1_SIZE & 0,217 & 1,995 & 0,829 & 0,05 & Rejected \\
X2_AGE & 0,773 & 1,995 & 0,442 & 0,05 & Rejected \\
X3_IND & 1,873 & 1,995 & 0,065 & 0,05 & Rejected \\
X4_CR & $-3,459$ & $-1,995$ & 0,001 & 0,05 & Accepted \\
X5_ROA & 0,776 & 1,995 & 0,440 & 0,05 & Rejected \\
X6_DER & $-3,798$ & $-1,995$ & 0,000 & 0,05 & Accepted \\
X7_DIR & 0,513 & 1,995 & 0,610 & 0,05 & Rejected \\
X8_COM & 0,133 & 1,995 & 0,894 & 0,05 & Rejected \\
X9_AUD & 0,494 & 1,995 & 0,623 & 0,05 & Rejected \\
X10_PUB & $-0,990$ & $-1,995$ & 0,326 & 0,05 & Rejected \\
\hline
\end{tabular}

Source : Data Analysis Result (SPSS)

* Corresponding author's e-mail: belasulistyaguna@icloud.com

http://openjournal.unpam.ac.id/index.php/JIA 
Jurnal Ilmiah Akuntansi Universitas Pamulang - Vol. 9, No. 1, Januari 2021 -

Sulistyaguna et al

\section{The Coefficient of Determination (R2) Test}

Based on the table below, it can be seen the value of $\mathrm{R}$ is 0,564 . It means that the correlation between the independent variables on CSR disclosure in the amount of 0,564 . It means, there is a close relationship be-cause the value is close to 1 . While the value of Adjusted $\mathrm{R}^{2}$ obtained at 0,218 or $21,8 \%$, it means that the percentage of the contribution of independent variables to influence on CSR disclosure and the rest $(78,2 \%)$ is the influence of the other variables that are not included in this research.

Table 10: Coefficient of Determination (R2) Test

\begin{tabular}{ccccc}
\hline $\mathrm{R}$ & $\begin{array}{c}\mathrm{R} \text { Square } \\
\left(\mathrm{R}^{2}\right)\end{array}$ & $\begin{array}{c}\text { Adjusted } \mathrm{R} \\
\text { Square }\end{array}$ & $\begin{array}{c}\text { Std. Error of the } \\
\text { Estimate }\end{array}$ & Description \\
\hline 0,564 & 0,318 & 0,218 & 0,14800 & Influential $21,8 \%$ \\
\hline
\end{tabular}

Source : Data Analysis Result (SPSS)

\section{Discussion}

The result shows that company size has no influence on the CSR disclosure. Small companies and large companies are required to carry out CSR because the company's operating activities have an impact on the environment around the company. This study in line with Wuttichindanon (2017).

The result shows that company age has no influence on the CSR disclosure. A company that has an older age is not affected to undertake more social disclosure because they have been used to make social responsibility to the community and environment by using other media such as the internet and magazines. This study is in line with Issa (2017).

The result shows that industry type has no influence on the CSR disclosure. Companies that are said to be high profile or low profile are both trying to make a wider disclosure of CSR disclosure to provide benefits to its stakeholders. This study is in line with Al-Gamrh \& Al-Dhamari (2016).

The result shows that liquidity has a negative effect on CSR disclosure. A favourable financial condition the firm does not have a special concern on CSR disclosure. Thus, the higher liquidity will reduce the level of CSR disclosure. This study is in line with Gantyowati \& Agustine (2017) on Malaysian companies.

The result shows that profitability has no influence on the CSR disclosure. It is associated with the view that a CSR disclosure provides a competitive disadvantage because companies have to incur additional costs to disclose CSR information. Consequently, it will decrease the profits from sales or revenue. This study in line with Dyduch \& Krasodomska (2017).

The result shows that leverage has a negative influence on the CSR disclosure. This negative relationship can be explained where companies that have a large dependence on creditors will try to reduce the focus of debt holder by reducing the disclosure of social responsibility. This study is in line with Akanfe et al (2017).

The result shows that board of directors has no influence on the CSR disclosure. The role of the board of directors can not provide evidence due to lack of duties and roles within the company as well as at least the number of boards of

* Corresponding author's e-mail: belasulistyaguna@icloud.com

http://openjournal.unpam.ac.id/index.php/JIA 
Jurnal Ilmiah Akuntansi Universitas Pamulang - Vol. 9, No. 1, Januari 2021 -

Sulistyaguna et al

directors. This study is in line with Vu \& Buranatrakul (2018).

The result shows that board of commissioners has no influence on the CSR disclosure. The bigger board of commissioners, the more parties there will be supervise management, it makes ineffective because every board of commissioners has different interests. This study is in line with Anam et al (2018).

The result shows that audit committee has no influence on the CSR disclosure. This is because the effectiveness of the audit committee is not based on the number of audit members but from the quality of existing HR. This study is in line Dias et al (2017).

The result shows that public ownership has no influence on the CSR disclosure. The public ownership benefits only for the shareholders based on the dividends distributed, while implementing CSR according to GRI guidelines must be able to provide benefits to all interested parties in company in the long run. This study is in line with Ramadhani \& Agustina, (2019).

\section{CONCLUSION}

Based on the results, it can be concluded that liquidity and leverage had an influence on the corporate social responsibility disclosure, while company age, industry type, profitability, board of directors, board of commissioners, audit committee and public ownership had no influence on the corporate social responsibility disclosure.

The limitations of this study is limited to the Indonesian companies, so the results can not be generalized with the entire companies in the world. Based on the results and conclusions above, the recommendations that can be given for further research is suggested to use samples of companies from other countries and it is expected to add other variables that can influence corporate social responsibility disclosure.

\section{REFERENCES}

Akanfe, S. K., Michael, S. O., \& Bose, A. D. (2017). Determinant of Corporate Social Responsibility Disclosure in Nigeria. International Journal of Academic Research in Business and Social Sciences, 7(7), 565-580.

Al-Gamrh, B. A., \& Al-Dhamari, R. A. (2016). Firm Characteristics and Corporate Social Responsibility Disclosure. International Business Management 10, 18, 4283-4291.

Anam, H., Sudjinan, Sudarmo, \& Mega A. (2018). The Influence of Good Corporate Governance, Profitability, and Leverage Toward Disclosure of Corporate Social Responsibility. Research Journal of Finance and Accounting, 9(18), 78-85.

* Corresponding author's e-mail: belasulistyaguna@icloud.com

http://openjournal.unpam.ac.id/index.php/JIA 
Jurnal Ilmiah Akuntansi Universitas Pamulang - Vol. 9, No. 1, Januari 2021 -

Sulistyaguna et al

Anatami, D. N., Nurkholis, \& Roekhudin. (2019). The Determinants of Corporate Social Responsibility Disclosure with Environmental Performance as Moderating Variables. International Journal of Business, Economics and Law, 18(5), 236-247.

Ariyani, A. P., \& Hartomo, O. D. (2018). Analysis of Key Factors Affecting the Reporting Disclosure Indexes of Sustainability Reporting in Indonesia. International Journal of Business, Economics and Law, 16(1), 15-25.

Coluccia, D., Fontana, S., \& Solimene, S. (2018). Does Institutional Context Affect CSR Disclosure? A Study on Eurostoxx 50. Sustainability, 10, 1-20.

Dias, A., Rodrigues, L. L., \& Craig, R. (2017). Corporate Governance Effects on Social Responsibility Disclosures. Australasian Accounting, Business and Finance Journal, 11(2).

Dyduch, J., \& Krasodomska, J. (2017). Determinants of Corporate Social Responsibility Disclosure: An Empirical Study of Polish Listed Companies. Sustainability, 9, 1-24.

Gantyowati, E., \& Agustine, K. F. (2017). Firm's Characteristics and CSR Disclosure, Indonesia and Malaysia Cases. Review of Integrative Business and Economics Research, 6(3), 131-145.

Hackston, D., \& Milne, M. (1996). Some Determinants of Social and Environmental Disclosures in New Zealand Companies. Accounting, Auditing \& Accountability Journal, 9(1), 77-108.

Handayati, P., \& Rochayatun, S. (2015). The Effect of Environmental Performance and Corporate Governance Mechanism on the Corporate Social Responsibility Disclosure. International Journal of Business, Economics and Law, 8(1), 80-87.

Hermawan, A., \& Gunardi, A. (2019). Motivation for Disclosure of Corporate Social Resposibility: Evidence from Banking Industry in Indonesia. Entrepreneurship and Sustainability Issues, 6(3), 1297-1306.

Issa, A. I. (2017). The Factors Influencing Corporate Social Responsibility Disclosure in the Kingdom of Saudi Arabia. Australian Journal of Basic and Applied Sciences, 11(10), 1-19.

Joshi, G., \& Hyderabad, R. (2019). Determinants of Corporate Social Responsibility Reporting in India. Journal of Management (JOM), 6(1), 110.

Mukhtaruddin, Saftiana, Y., \& Dwikatama, P. A. (2018). Firm's Characteristics, Corporate Governance Quality and Corporate Social Responsibility Disclosure. Sriwijaya International Journal of Dynamic Economics and Business, SIJDEB 2(3), 193-212.

Naseem, M. A., Riaz, S., Rehman, R. U., Ikram, A., \& Malik, F. (2017). Impact of Board Characteristics on Corporate Social Responsibility Disclosure. The Journal of Applied Business Research, 33(4), 801-810.

* Corresponding author's e-mail: belasulistyaguna@icloud.com

http://openjournal.unpam.ac.id/index.php/JIA 
Jurnal Ilmiah Akuntansi Universitas Pamulang - Vol. 9, No. 1, Januari 2021 -

Sulistyaguna et al

Nasution, A. H., Erlina, \& Tamizi, H. (2018). An Analysis on the Influence of Profitability, Firm Size, Liquidity and Leverage on the Expression of Firm's Social Responsibility in Banking Companies Listed in BEI (Indonesian Stock Exchange). International Journal of Research and Review, 5(9).

Osei, A. A., Yusheng, K., Caesar, A. E., \& Tawiah, V. K. (2017). Impact of Gender Diversity on Corporate Social Responsibility Disclosure (CSRD) in Ghana. International Journal of Economics Review \& Business Research, 4(2), 124.

Ramadhani, C. F., \& Agustina, L. (2019). Influence of Company Characteristics on Corporate Social Responsibility Disclosures in the Annual Reports of the Manufacturing Companies. Accounting Analysis Journal, 8(1), 24-30.

Salehi, M., Tarighi, H., \& Rezanezhad, M. (2019). Empirical Study on the Effective Factors of Social Responsibility Disclosure of Iranian Companies. Journal of Asian Business and Economic Studies, 26(1), 34-55.

Santika, S., Roekhudin, \& Saraswati, E. (2019). The Determination Factors On Disclosure Of Corporate Social Responsibility and Its Impact for Company Value. South East Asia Journal of Contemporary Business, Economics and Law, 18(5), 23-32.

Suhartono, S, I. M., \& Wahyuni, S. (2018). IFRS Convergence Inverstigation: Corporate Social Responsibility Disclosure in Relation to Good Corporate Governance and Corporate Size. PEOPLE: International Journal of Social Sciences, 4(2), 531-546.

Vu, K. A., \& Buranatrakul, T. (2018). Corporate Social Responsibility Disclosure in Vietnam: A Longitudinal Study. DLSU Business \& Economics Review, 27(2), 147-165.

Wuttichindanon, S. (2017). Corporate social responsibility disclosuredchoices of report and its determinants: Empirical evidence from firms listed on the Stock Exchange of Thailand. Kasetsart Journal of Social Sciences, 38, 156162.

Zaid, M., \& Nasiri, A. (2018). The Effects of Firm Characteristics on Corporate Social Responsibility Disclosure: Evidence from Palestine. Research Journal of Finance and Accounting, 9(13), 46-53.

* Corresponding author's e-mail: belasulistyaguna@icloud.com

http://openjournal.unpam.ac.id/index.php/JIA 